\title{
Aminotransferase Activity of Hartmannella (Culbertson Strain A-1) Grown Axenically
}

\author{
By M. M. HUSAIN AND V. K. MOHAN RAO \\ Division of Biochemistry, \\ Central Drug Research Institute, Lucknow, India
}

(Accepted for publication 24 February 1969)

\section{SUMMARY}

Cell-free extracts of trophozoites of Hartmannella (Culbertson strain A-I), grown axenically, catalysed transamination between 2-oxoglutarate and a number of amino acids. Aspartic acid, alanine and serine showed the maximum activity. The L-alanine-2-oxoglutarate aminotransferase (E.C. 2.6. I.2) was purified about $\mathrm{I} 5$-fold by adsorption with calcium phosphate gel and elution with $0.2 \mathrm{M}$-phosphate buffer. Stability during storage, $\mathrm{pH}$ optima in different buffers $K_{m}$ values for alanine and 2-oxoglutarate, and the role of pyridoxal-5-phosphate are reported. $p$-Chloromercuribenzoate, cyanide and metal-chelating agents markedly inhibited the enzyme. Among dicarboxylic acids, maleic acid had the maximum inhibitory effect. Amoebicidal drugs and antibiotics had no marked inhibitory effect on the enzyme.

\section{INTRODUCTION}

Certain strains of the free-living amoebae belonging to the genus Hartmannella (Acanthamoeba) produce meningoencephalitis in mice and monkeys and are supposed to cause the same disease in man (Culbertson, Smith, Cohen \& Minner, I959; Patras \& Andujar, 1966; Butt, 1966). The growth, nutritional requirements and metabolic activities (Adam, I959, I964; Band, 1959, I96I, I962; Neff, 1957) of some of these strains have also been studied. The patterns of the proteolytic activities of Hartmannella (Ambrosioni, I952; Bianchini, I953 $a, b$ ) and Acanthamoeba (Jarumilinta \& Maegraith, 196r $a, b$ ) have been reported, using different substrates. In the intermediary metabolism of proteins and in the formation of pool amino-acids, transaminases play an important role. In view of this, the aminotransferase (E.C. 2.6.I.2) activity present in crude cell-free extract of trophozoites of Hartmannella has been partially purified and characterized. The action of certain amoebicidal drugs and antibiotics has also been studied and the results are presented in this communication.

\section{METHODS}

Source of enzyme. Pathogenic Hartmannella strain A-I, obtained from Dr C. G. Culbertson, was cultured axenically in medium containing Difco Proteose-peptone ( $\mathrm{I} \%, \mathrm{w} / \mathrm{v})$, Oxoid tryptone (I \%, w/v) and sodium chloride $(0.5 \%, \mathrm{w} / \mathrm{v}), \mathrm{pH} 6 \cdot 8$, in I 1. Roux flasks. After 6 days at $37^{\circ}$, trophozoites were harvested and washed three times with glass-distilled water. The washed cells were suspended in water and 
homogenized in a Potter-Elvehjem glass homogenizer at $4^{\circ}$. The homogenate was centrifuged at $3000 \mathrm{rev} . / \mathrm{min}$. in a MSE refrigerated centrifuge for $30 \mathrm{~min}$. The resulting opalescent crude enzyme extract was purified over calcium phosphate gel.

\section{Assay of enzyme activity}

Colorimetric method. Glutamate-pyruvate transaminase (GPT) was estimated by the method of Reitman \& Frankel (1957). In a typical assay system, $0.2 \mathrm{ml}$. of the enzyme was incubated for $60 \mathrm{~min}$. with $2 \mu$ mole 2 -oxoglutarate, $200 \mu$ mole DL-alanine and $100 \mu$ mole Sørensen phosphate buffer $\left(\mathrm{pH}_{7} \cdot 4\right)$; total volume $\mathrm{I} \cdot 2 \mathrm{ml}$. The reaction was stopped by addition of $\mathrm{I} \mathrm{ml}$. of $0.02 \%(\mathrm{w} / \mathrm{v})$ 2,4-dinitrophenylhydrazine in $2 \mathrm{~N}-\mathrm{HCl}$. After 20 min. colour was developed by the addition of $\mathrm{I} 0 \mathrm{ml}$. of $0.4 \mathrm{~N}-\mathrm{NaOH}$ and the intensity of the colour was read at $505 \mathrm{~m} \mu$ in a Beckman DU model spectrophotometer. Enzyme units were calculated from a standard curve for the extinction of dinitrophenyl-hydrazones of pyruvate in conditions similar to those of enzyme assay.

Chromatographic method. Wherever the above method could not be applied, paper chromatography was used for estimating the glutamate formed during transamination. The chromatogram was run for $16 \mathrm{hr}$ in $n$-butanol + acetic acid + water $(4+\mathrm{I}+\mathrm{I} \mathrm{v} / \mathrm{v})$ and the amino acid spots, after developing with ninhydrin, were quantitated according to the method of Giri, Radhakrishnan \& Vaidyanathan (1952). In a typical assay, $0.5 \mathrm{ml}$. of reaction mixture contained $\mathrm{I}$ to $20 \mu$ mole 2 -oxoglutarate, I to ro $\mu$ mole DL-alanine and $20 \mu$ mole phosphate buffer, $(\mathrm{pH} 7 \cdot 4$ ). The reaction was run for $4 \mathrm{hr}$ at $37^{\circ}$, stopped by heating $5 \mathrm{~min}$. in a boiling water bath and the chromatograms were run using $0.02 \mathrm{ml}$. reaction mixture. Independent experiments (without enzyme) showed that under these conditions non-enzymic transamination did not occur due to heating.

Estimation of protein. Protein in the extract was estimated by the method of Lowry, Rosebrough, Farr \& Randall (195I), with bovine plasma albumin as standard.

Preparation of calcium phosphate gel. Calcium phosphate gel was prepared according to the method of Keilin \& Hartree (1938) and about 8-months old gel was used for adsorption purposes.

Chemicals and reagents. DL-alanine and 2-oxoglutarate (B.D.H.) and pyridoxal-5phosphate (E. Merck) were used. All other reagents were of analytical grade.

Samples of paromomycin sulphate (Parke Davis (India) Ltd.), chlortetracycline hydrochloride (Aureomycin: Cyanamide (India) Ltd.), cycloheximide (Actidione: Upjohn Co., U.S.A.), 4-carbamidophenyl arsonic acid (Carbarsone: Burroughs Wellcome and Co. (India), Private Ltd.), chloroquine phosphate and emetine hydrochloride (Bengal Immunity Co. Ltd.), iodochlorhydroxyquin (Enterovioform: CIBA of India Ltd.) and chlorhexidine dihydrochloride (I.C.I.) were employed in these studies.

\section{RESULTS}

Preliminary screening of the crude extract of trophozoites of Hartmannella for aminotransferase activity, using 20 common amino acids as amino-group donors and the chromatography technique, revealed that 2-oxoglutarate was a more effective amino group acceptor than pyruvate or oxalacetate. Results with some of the active amino acids are given in Table $\mathrm{I}$. 
Purification of the enzyme. Table 2 illustrates partial purification of the enzyme activity by calcium phosphate gel adsorption and elution by different molar concentrations of phosphate buffer. The most active enzyme protein was eluted by $0.2 \mathrm{M}$ phosphate buffer. Due to a paucity of material further purification was not attempted. In the following experiments about 15 -fold purified enzyme was utilized for the estimation of GPT activity.

Table I. Aminotransferase activity of cell-free extracts of Hartmannella (Culbertson strain $A-I$ ) in 2-oxoglutarate system

Donor amino acid

L-Alanine
L-Aspartic acid
L-Cysteine
DL-Isoleucine
L-Methionine
L-Serine
L-Valine

$\mu$ mole glutamic acid formed per mg. protein

I0
I3
3
3
$0 \cdot 7$
8
6

Reaction conditions: $0.2 \mathrm{ml}$. of cell-free enzyme extract ( $43 \mu \mathrm{g}$. protein), $10 \mu$ mole 2 -oxoglutarate, Io $\mu$ mole L-amino acid ( $20 \mu$ mole in the case of DL-amino acid), $20 \mu$ mole Sørensen phosphate buffer $\left(\mathrm{pH}_{7} \cdot 4\right)$, total volume $0.5 \mathrm{ml}$; incubation $4 \mathrm{hr}$ at $37^{\circ} .0 .02 \mathrm{ml}$. of reaction mixture was used for the paper chromatographic estimation of glutamic acid formed.

Table 2. Purification of alanine-2-oxoglutarate aminotransferase activity of Hartmannella (Culbertson strain $A-I$ )

\begin{tabular}{|c|c|c|c|c|c|}
\hline Step & $\begin{array}{l}\text { Vol. } \\
\text { (ml.) }\end{array}$ & $\begin{array}{l}\text { Protein } \\
\text { (mg.) }\end{array}$ & $\begin{array}{c}\text { Activity } \\
\text { units* } \times \text { 100 }\end{array}$ & $\begin{array}{l}\text { Specific } \\
\text { activity }\end{array}$ & $\begin{array}{c}\text { Fold } \\
\text { purification }\end{array}$ \\
\hline Crude extract & 7 & $18 \cdot 9$ & 126 & 666 & $\mathbf{I}$ \\
\hline $\begin{array}{l}\text { Addition of calcium phosphate } \\
\text { gel }\end{array}$ & 7 & - & - & - & 一 \\
\hline $\begin{array}{l}\text { Unadsorbed fraction } \\
\text { Elution with phosphate buffer } \\
\text { pH } 7 \cdot 4\end{array}$ & $7 \cdot 6$ & $4 \cdot 9$ & 一 & - & - \\
\hline $0.05 \mathrm{M}$ & 5 & $2 \cdot 6$ & - & 一 & - \\
\hline $0.05 \mathrm{M}$ & 5 & $\mathrm{I} \cdot 6$ & - & - & - \\
\hline $0.1 \mathrm{M}$ & 5 & $I \cdot 2$ & $42 \cdot 5$ & $3,54 \mathrm{I}$ & $5 \cdot 5$ \\
\hline O.I M & 5 & 0.8 & 30 & 3,750 & $5 \cdot 7$ \\
\hline $0.2 \mathrm{M}$ & 5 & $I \cdot I$ & 95 & 8,636 & 13 \\
\hline $0.2 \mathrm{M}$ & 5 & 0.5 & 55 & I I ,000 & 16.5 \\
\hline
\end{tabular}

* One unit of enzyme produces I m $\mu$ mole pyruvate in $60 \mathrm{~min}$. at $37^{\circ}$. Reaction conditions: $0.2 \mathrm{ml}$. enzyme, $2 \mu$ mole 2-oxoglutarate, $200 \mu$ mole DL-alanine, I00 $\mu$ mole Sørensen phosphate buffer (pH 7.4), total volume $\mathrm{I} \cdot 2 \mathrm{ml}$; incubation $60 \mathrm{~min}$. at $37^{\circ}$.

\section{Properties of the enzyme}

Stability. The partially purified enzyme solution was distributed into two tubes which were stored separately at $4^{\circ}$ and $-10^{\circ}$ and assayed for GPT activity at intervals. Enzyme stored at $4^{\circ}$ progressively lost more than half of its activity in 20 days, while freezing the enzyme extract at $-10^{\circ}$ for 2 days and thawing resulted in the loss of more than half of its activity.

Coenzyme requirement. Enzyme preparations, one dialysed overnight at $4^{\circ}$ and 
the other undialysed, were incubated with various concentrations of pyridoxal-5phosphate for $15 \mathrm{~min}$. and their activities determined. Figure I demonstrates that the coenzyme dissociated to some extent from the apoenzyme and higher concentrations of coenzyme inhibited the GPT activity.

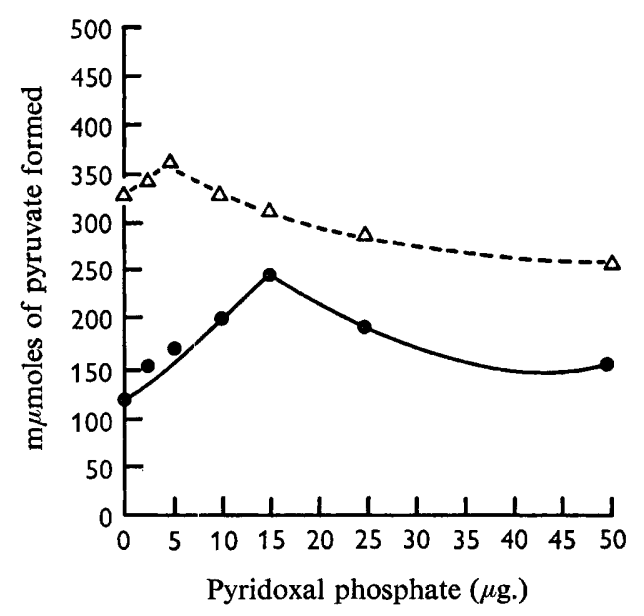

Fig. I. Cofactor requirement of alanine-2-oxoglutarate aminotransferase of Hartmannella (Culbertson strain A-I). The enzyme was preincubated with pyridoxal-5-phosphate (o to $50 \mu \mathrm{g}$.) for $15 \mathrm{~min}$. Reaction conditions: $0.2 \mathrm{ml}$. enzyme $(8 \mu \mathrm{g}$. dialysed protein, I I $\mu \mathrm{g}$. undialysed protein), $2 \mu$ mole 2 -oxoglutarate, $200 \mu$ mole DL-alanine, $100 \mu$ mole Sørensen phosphate buffer $(\mathrm{pH} 7 \cdot 4)$, total volume $\mathrm{I} \cdot 2 \mathrm{ml}$; incubation $60 \mathrm{~min}$. at $37^{\circ}$. Enzyme dialysed; $\triangle--\triangle$, undialysed.
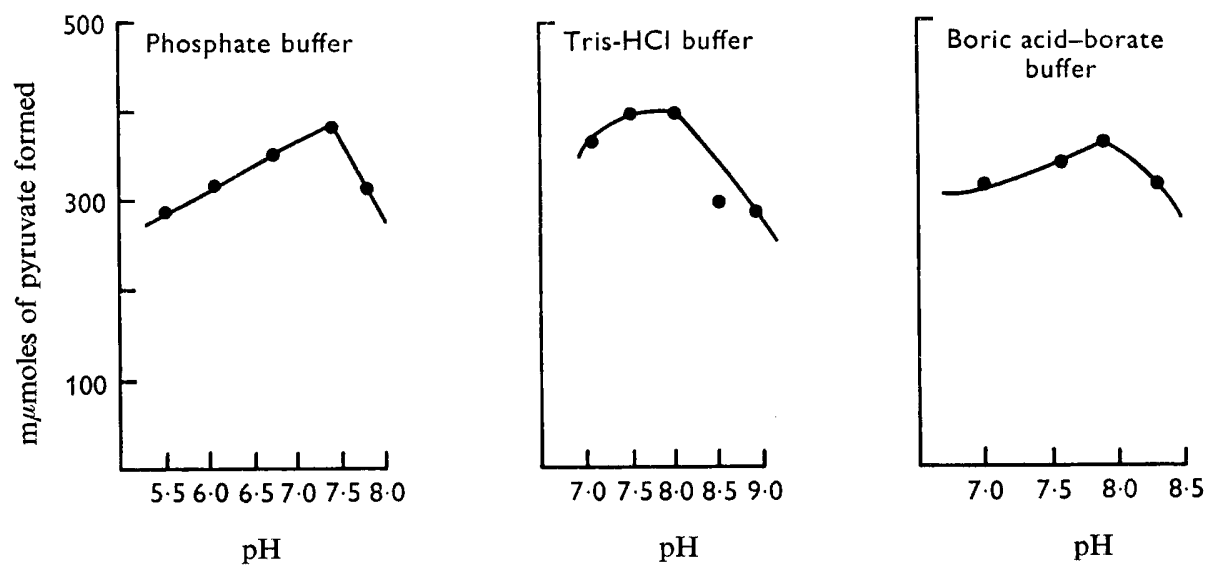

Fig. 2. Effect of pH on the alanine-2-oxoglutarate aminotransferase activity of Hartmannella (Culbertson strain A-I). Reaction conditions: $0.2 \mathrm{ml}$. enzyme (2I $\mu \mathrm{g}$. protein), $2 \mu$ mole 2-oxoglutarate, $200 \mu$ mole DL-alanine, I00 $\mu$ mole phosphate, tris- $\mathrm{HCl}$, or boric acid-borate buffers, total volume $\mathrm{I} \cdot 2 \mathrm{ml}$., incubation $60 \mathrm{~min}$. at $37^{\circ}$. Enzyme preincubated $15 \mathrm{~min}$. with $5 \mu \mathrm{g}$. pyridoxal-5-phosphate.

Time-activity relationship. Thirty $\mu \mathrm{g}$. protein incubated for $15 \mathrm{~min}$. with $5 \mu \mathrm{g}$. pyridoxal phosphate (conditions otherwise as for Fig. I) formed pyruvate linearly for $45 \mathrm{~min}$. and reached a maximum by $60 \mathrm{~min}$. 
Enzyme concentration. In similar experimental conditions the relationship between the amount of pyruvate formed and enzyme protein was linear between 7.5 and $60 \mu \mathrm{g}$.

Effect of $\mathrm{pH}$. The optimum $\mathrm{pH}$ in phosphate buffer was at $7 \cdot 4$, in tris- $\mathrm{HCl}$ buffer in the range $7 \cdot 5-8 \cdot 0$ and in borate buffer at $7 \cdot 9$ (Fig. 2).

$K_{m}$ values for substrates. Amounts of glutamic acid formed at different concentrations of alanine and 2-oxoglutarate were estimated. The $K_{m}$ value for alanine was $2 \cdot 22 \times 10^{-3} \mathrm{M}$ (Fig. 3) and for 2-oxoglutarate $7 \cdot \mathrm{I} \times \mathrm{IO}^{-3} \mathrm{M}$ (Fig. 4).
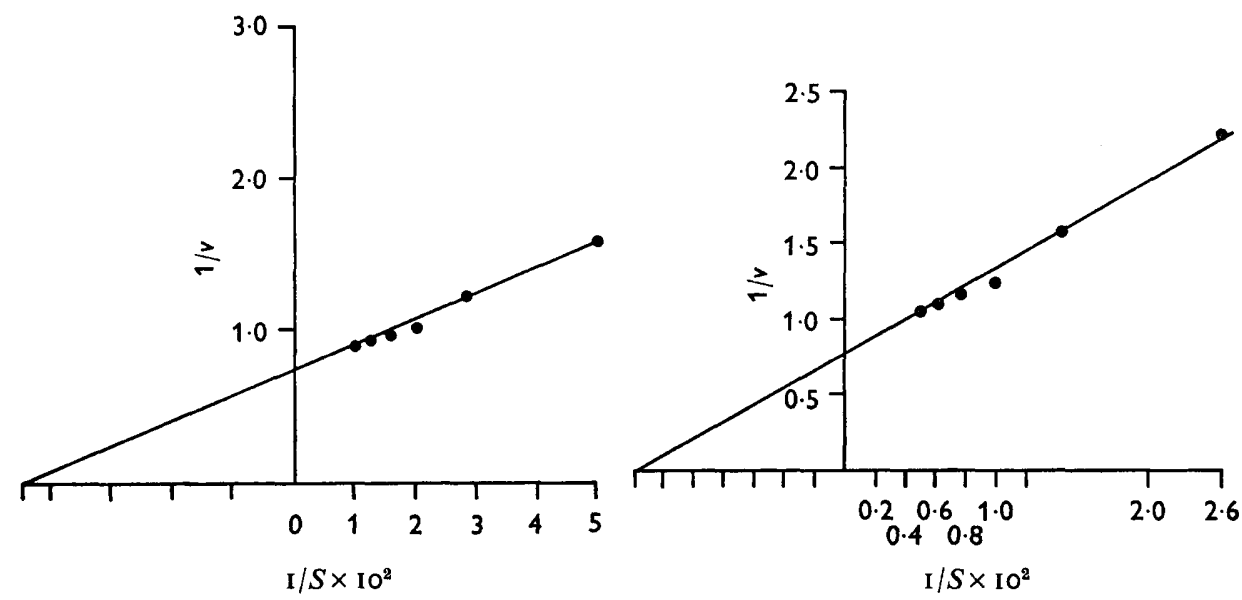

Fig. 3. Determination of $K_{m}$ value for alanine. Reaction conditions: $0.2 \mathrm{ml}$. enzyme (96 $\mu \mathrm{g}$. protein), Io $\mu$ mole 2-oxoglutarate, o to Io $\mu$ mole DL-alanine, $20 \mu$ mole Sørensen phosphate buffer, total volume $0.5 \mathrm{ml}$.; incubation $4 \mathrm{hr}$ at $37^{\circ} .0 .02 \mathrm{ml}$. reaction mixture was used for paper chromatographic estimation of glutamic acid formed.

Fig. 4. Determination of $K_{m}$ value for 2-oxoglutarate. Reaction conditions: $0.2 \mathrm{ml}$. enzyme (72 $\mu \mathrm{g}$. protein), Io $\mu$ mole DL-alanine, o to Io $\mu$ mole 2-oxogluterate, $20 \mu$ mole Sørensen phosphate buffer, total volume $0.5 \mathrm{ml}$.; incubation $4 \mathrm{hr}$ at $37^{\circ} .0 .02 \mathrm{ml}$. reaction mixture was used for paper chromatographic estimation of glutamic acid formed.

Effect of inhibitors. The actions of some common inhibitors on the enzyme activity are summarized in Table 3. Carbonyl agents such as hydrazine sulphate inhibited the enzyme by a quarter, while hydroxylamine hydrochloride inhibited the enzyme by about half. Metal chelating agents, $o$-phenanthroline, 8-hydroxyquinoline and $\alpha, \alpha^{\prime}$-dipyridyl, markedly inhibited the enzyme, while EDTA had a slight stimulatory effect. Salts of heavy metals such as copper sulphate and mercuric chloride completely inactivated the enzyme. Structural analogues of pyridoxal-5-phosphate, namely isonicotinic acid hydrazide (INH) and pyridine-3-sulphonic acid at $5 \times 1 \mathrm{I}^{-3} \mathrm{M}$, inhibited the enzyme by only about one-fourth to one-fifth. Neither of these inhibitions could be annulled by Io $\mu \mathrm{g}$. of the cofactor. Most of the enzyme activity was inhibited by $1 \mathrm{O}^{-3} \mathrm{M}$ sodium cyanide. The sulphydryl reagent $p$-chloromercuribenzoate $(p \mathrm{CMB})$ at $\mathrm{IO}^{-4} \mathrm{M}$ completely inhibited the enzyme, while $\mathrm{IO}^{-3} \mathrm{M}$-iodoacetate had no effect on the enzyme activity. The inhibitory action of $p \mathrm{CMB}$ could not be annulled by $5 \times 1 \mathrm{O}^{-5} \mathrm{M}-$ cysteine. Cysteine at $\mathrm{IO}^{-2} \mathrm{M}$ concentration, at neutral $\mathrm{pH}$, inhibited the enzyme completely, but at $5 \times 10^{-5} \mathrm{M}$ it activated the enzyme by a quarter.

Effect of dicarboxylic acids. Fumarate, malate, succinate had a slight inhibitory 
Table 3. Effect of activators and inhibitors on alanine-2-oxoglutarate aminotransferase activity of Hartmannella (Culbertson strain $A-I$ )

\section{Activator/Inhibitor}

Hydroxylamine hydrochloride

Hydrazine sulphate

Sodium iodoacetate

Sodium cyanide

Isonicotinic acid hydrazide (INH)

Pyridine-3-sulphonic acid

p-Chloromercuribenzoate (pCMB)

8-OH-quinoline

EDTA

$\alpha, \alpha^{\prime}$-Dipyridyl

$o$-Phenanthroline

Sodium succinate

Sodium fumarate

Sodium malate

Sodium maleate

Sodium oxalate

Copper sulphate

Mercuric chloride

Cysteine hydrochloride

$p \mathrm{CMB}$

Cysteine hydrochloride

$p \mathrm{CMB}+$ cysteine hydrochloride

Pyridine-3-sulphonic acid

Pyridine-3-sulphonic acid + Io $\mu \mathrm{g}$.

pyridoxal-5-phosphate

INH

INH + Io $\mu$ g. pyridoxal-5-phosphate

\section{Concentration}

(M)

$1 \times 10^{-4}$

$1 \times 10^{-4}$

$1 \times 10^{-4}$

$\mathrm{I} \times 10^{-3}$

$1 \times 10^{-2}$

$1 \times 10^{-3}$

$1 \times 10^{-4}$

$1 \times 10^{-2}$

$1 \times 10^{-2}$

$1 \times 10^{-2}$

$1 \times 10^{-2}$

$1 \times 10^{-2}$

$1 \times 10^{-2}$

$1 \times 10^{-2}$

$1 \times 10^{-2}$

$\mathrm{I} \times \mathrm{IO}^{-2}$

$3.6 \times 10^{-4}$

$5 \times 10^{-4}$

$1 \times 10^{-2}$

$5 \times 10^{-5}$

$5 \times 10^{-5}$

$5 \times 10^{-5}$ each

$5 \times 10^{-3}$

$5 \times 10^{-3}$ each

$5 \times 10^{-3}$
$5 \times 10^{-3}$ each
Inhibition

$(\%)^{*}$

$-54$

$-25$

Nil

$-95$

$-22$

$-96$

$-100$

$-88$

$+8$

$-6 \mathrm{I}$

$-91$

$-6$

- I 5

$-22$

$-52$

$+10$

$-100$

$-100$

$-100$

$-100$

$+26$

$-100$

$-29$

$-30$

$-17$

$0.2 \mathrm{ml}$. inhibitor/activator or water (control) was incubated with $0.2 \mathrm{ml}$. enzyme for $15 \mathrm{~min}$. and then $1 \mathrm{ml}$. of the buffered substrate (containing $2 \mu$ mole of 2 -oxoglutarate and $200 \mu$ mole of DLalanine and $100 \mu$ mole Sørensen phosphate buffer at $\mathrm{pH} 7.4$ ) was added. The reaction was then run for $60 \mathrm{~min}$. at $37^{\circ}$.

* - , Inhibition; + , Activation.

Table 4. Effect of amoebic drugs and antibiotics on alanine-2-oxoglutarate aminotransferase of Hartmannella (Culbertson strain $A-I$ )

\section{Drugs}

Inhibition

Cycloheximide

Chlortetracycline hydrochloride

4-Carbamidophenyl arsonic acid

14

Chlorhexidine dihydrochloride

20

Chloroquine phosphate

Emetine hydrochloride

Iodochlorhydroxyquin

Paromomycin sulphate

$0.2 \mathrm{ml}$. of enzyme ( $36 \mu \mathrm{g}$. protein) was preincubated for $15 \mathrm{~min}$. with $0.2 \mathrm{ml}$. of respective drug ( $\mathrm{mg} . / \mathrm{ml}$.) or water (control) and the reaction was run as described in Table 3. 
effect on the enzyme, while oxalate had a slight stimulatory influence. Only maleate inhibited the enzyme by half.

Effect of antiamoebic drugs and antibiotics. The action of some antiamoebic drugs and antibiotics on the GPT of Hartmannella are presented in Table 4. Chlorhexidine dihydrochloride inhibited the enzyme by one-third. None of the antibiotics inhibited the enzyme markedly. Among the other potent amoebicidal drugs, 4-carbamidophenyl arsonic acid inhibited the enzyme to the maximum extent of one-fifth, while the remaining three drugs, namely emetine hydrochloride, chloroquine phosphate and iodochlorhydroxyquin, inhibited it by about one-tenth.

\section{DISCUSSION}

Just like in the aminotransferase system of Entamoeba histolytica (Mohan Rao \& Dutta, I966), 2-oxoglutarate was the most active amino-group acceptor compared with pyruvate and oxalacetate in the Hartmannella system. Valine, asparagine, leucine and aspartic acid have been reported to be the most active amino-group donors to 2-oxoglutarate in $E$. histolytica system, but in the Hartmannella aspartic acid, serine and alanine were most active. Serine was actively transaminated by Hartmannella, whereas $E$. histolytica failed to transaminate serine under similar experimental conditions. While Hartmannella poorly transaminated leucine, the same amino acid was actively transaminated by $E$. histolytica (Mohan Rao \& Dutta, I966). Amoebicidal drugs and antibiotics had almost the same type of effect either on Hartmannella or E. histolytica (Mohan Rao \& Dutta, I966) enzymes. In both these enzyme systems the maximum inhibition of about $30 \%$ was effected by chlorhexidine dihydrochloride.

Higher concentrations of pyridoxal-5-phosphate inhibited either dialysed or undialysed enzyme extracts of Hartmannella. Similar findings were reported with the aminotransferase systems of E. histolytica (Mohan Rao \& Dutta, 1966), animal tissues (Roberts \& Bregoff, I953) and human intestines (Ramaswamy \& Radhakrishnan, 1964).

The inhibition caused by some dicarboxylic acids, especially by maleate, may be explained on the basis of an earlier observation (Jenkins, David \& Irwin, 1959) that the enzyme forms an inactive complex with these acids.

The $K_{m}$ value for alanine for the aminotransferase activity of Hartmannella compares favourably with those reported for cotton seeds (Turano, Bossa, Fasella \& Fanelli, 1966) and equine erythrocytes (Balasarswathi \& Krishna Murti, I967).

The above discussion focuses some of the differences in the properties of aminotransferase activities of the two pathogenic amoebae, one belonging to free-living and the other to parasitic groups of organisms.

The authors are grateful to Dr M. L. Dhar, Director, for his keen interest in this work, and to Dr C. R. Krishna Murti and Dr B. N. Singh for helpful suggestions. The authors are very much obliged to Dr C. G. Culbertson, The Lilly Research Laboratories, Eli Lilly and Company, Indianapolis, U.S.A., for supplying the Hartmannella strain A-I. The authors are also indebted to the firms who supplied samples of drugs and antibiotics used in this investigation. The technical assistance of Mr S. K. Bose is gratefully acknowledged. One of the authors (M.M.H.) is grateful to the Council of Scientific \& Industrial Research, New Delhi, for awarding a Junior 
Research Fellowship. Communication no. I329 from the Central Drug Institute, Lucknow.

\section{REFERENCES}

ADAM, K. M. G. (I959). The growth of Acanthamoeba sp. in a chemically defined medium. J. gen. Microbiol. 2I, 519.

Adam, K. M. G. (1964). The amino acid requirements of Acanthamoeba. J. Protozool. II, 98.

Ambrosioni, P. (1952). Biology of Hartmannella castellanii. I. Some biochemical properties of Hartmannella castellanii and of the proteolytic enzymes produced by it. Riv. Patol. clin. 7, 90.

Balasarswathi, K. \& Krishna Murti, C. R. (1967). Partial purification and properties of L-alanine 2-oxoglutarate aminotransferase of equine red blood cells. Indian J. Biochem. 4, 22.

BAND, R. N. (1959). Nutritional and related biological studies on the free-living soil amoeba, Hartmannella rhysodes. J. gen. Microbiol. 21, 80.

BAND, R. N. (1961). Biotin, a growth requirement for four soil amoebae. Nature, Lond. 192, 674.

BAND, R. N. (1962). The amino acid requirements of the soil amoeba, Hartmannella rhysodes Singh. J. Protozool. 9, 377.

Bianchini, P. (1953a). Proteolytic enzymes of Hartmannella castellanii. Suggestion for a new quantitative method to determine the activity of gelatinase. Chem. Abstr. 47, I 269 b.

Bianchini, P. (1953b). A proteolytic enzyme excreted by Hartmannella castellanii. Chem. Abstr. 47, II319f.

ButT, C. G. (1966). Primary amoebic meningoencephalitis. New Engl. J. Med. 274, 1473.

Culbertson, C. G., Smith, J. W., Cohen, H. K. \& Minner, J. R. (I959). Experimental infection of mice and monkeys by Acanthamoeba. Am. J. Path. 35, 185.

GiRi, K. V., Radhakrishnan, A. N. \& Vaidyanathan, C. S. (1952). Some factors influencing the quantitative determination of amino acids separated by circular paper chromatography. Analyt. Chem. 24, 1677.

JARUMilintA, R. \& MAEGRAITH, B. G. (196i $a$ ). The patterns of some proteolytic enzymes of Entamoeba histolytica and Acanthamoeba sp. I. The action of E. histolytica and Acanthamoeba sp. on protein substrates. Ann. trop. Med. Parasit. 55, 505.

JaRUMilinta, R. \& MaEgraith, B. G. (196I $b$ ). The patterns of some proteolytic enzymes of Entamoeba histolytica and Acanthanoeba sp. II. Action of E. histolytica and Acanthamoeba sp. on various synthetic substrates. Ann. trop. Med. Parasit. 55, 5 I 8.

Jenkins, W. T., David, A. Y. \& IRwiN, W. S. (1959). Glutamic aspartic transaminase. I. Assay, purification and general properties. J. biol. Chem. 234, $5 \mathrm{I}$.

KeILIN, D. \& HaRTREe, E. F. (I938). On the mechanism of the decomposition of hydrogen peroxide by catalase. Proc. $R$. Soc. B 124, 397.

Lowry, O. H., Rosebrough, N. J., FarR, A. L. \& Randall, R. J. (I95I). Protein measurement with the Folin-phenol reagent. J. biol. Chem. 193, 265.

Mohan Rao, V. K. \& Durta, G. P. (1966). Transaminase activity of Entamoeba histolytica. Indian J. Microbiol. 6, 63.

NefF, R. J. (1957). Purification, axenic cultivation and description of a soil amoeba, Acanthamoeba sp. J. Protozool. 4, 176.

Patras, D. \& Andujar, J. J. (I966). Meningoencephalitis due to Hartmannella (Acanthamoeba). Am. J. clin. Path. 46, 226.

Ramaswamy, K. \& Radhakrishnan, A. N. (1964). Studies on intestinal transaminases with special reference to human intestinal glutamic aspartic transaminase. Indian J. Biochem. I, I.

Reitman, S. \& Frankel, S. (1957). A colorimetric method for the determination of serum glutamic oxaloacetic and glutamic pyruvic transaminases. Am. J. clin. Path. 28, 56.

RoBerts, E. \& Bregoff, H. M. (1953). Transamination of $\gamma$-amino-butyric acid and alanine in brain and liver. J. biol. Chem. 201, 393.

Turano, C., Bossa, F., Fasella, P. \& Fanelli, A. R. (1966). Purification and partial characterization of alanine oxoglutarate transaminase (AOT) from resting cotton seeds. Enzymologia 30, 185. 